\title{
Poezja Wielkiego Strajku - 1980
}

Roch Sulima 
クAPTS Seria III 1997

\section{Roch Sulima}

\section{Poezja Wielkiego Strajku - 1980}

1.

Strajk przeistaczający. Generalną refleksją, jaka narzuca się przy lekturze poezji strajkowej, jest może nie teza, lecz intuicja raczej o od n ow i e n i u symboli, znaczeń oraz form zbiorowych zachowań, jakie towarzyszyły pierwocinom zorganizowanych ruchów proletariackich, a przede wszystkim w okresie 1905-1907. Symbole i obrazy poetyckie, wypracowane lub zaakceptowane przez społeczność strajkową roku 1980, nawiązują i to raczej bezwiednie, do najdawniejszych, najbardziej elementarnych prawd zbiorowości robotniczej. Są one żywiołowym nawiązaniem do heroicznego wizerunku klas y ws tę p u ją c e j, do jej prawd wyjściowych, sformułowanych najostrzej w idealizacyjnych uogólnieniach znanych pierwocinom poezji robotniczej i proletariackiej. Wielki Powrót do źródeł grupowej tożsamości, formułowanej przed stu laty w obrazach i modelach idealnych, wynikał w pewnym sensie z modelowej pozycji strukturalnej, ze społecznej pozycji środowisk robotniczych, innymi słowy $-z$ ich spolecznego usytuowania przez pracę.

Te właśnie tradycje, ku niemałemu przecież zdumieniu, okazały się żywe. Nie ma tu bezpośrednich nawiązań tekstowych (te są bardzo rzadkie), ale są nawiązania bardziej generalne, nawiązania poprzez totalny charakter sytuacji strajkowej. Brak bezpośrednich zależności tekstowych świadczy m.in. o tym, że w grę wchodzi inny typ związków, inny charakter fundamentalnej tożsamości z sytuacją „wyjściową” oraz ciagłości ustanowionej przez inne „teksty-pośredniki”. Opisywanie tych „tekstów-pośredników” (tekstów w najszerszym rozumieniu) byłoby tu sprawą kluczową, odsłaniałoby istotne cechy kultury historycznej i politycznej robotników. Wiele elementów, charakterystycznych dla istnienia owych „tekstów-pośredników”, zaktywizowała w sposób integralny sama sytuacja strajkowa. 
Cechą istotną sytuacji strajkowej jest progresywnie ukierunkowana rzeczywistość stanı wyjątkowego. Społeczność np. „antologijną” zespala akceptacja wartości centralnych. Spo. łeczność strajkową natomiast zespala negacja tych wartości, wyrażonych przede wszystkin w symbolach sprawowania władzy, znakach administracji i oficjalnych organizacji społe. cznych. Abstrakcyjny związek z symbolami wartości centralnych, charakterystyczny dle społeczności klubowej i antologijnej, zostaje tu, przede wszystkim w pierwszej fazie strajku zastąpiony przez związek z wartościami bezpośrednimi, środowiskowymi i grupowymi a u t o ry te ta mi, z osobistymi dyspozycjami współtowarzyszy, przez przywiązanie do przywódców strajkowych. Społeczność strajkowa akcentuje najprostsze, pierwotne formy solidarności robotniczej, charakterystyczne dla pierwszych zbiorowych wystąpień robotników. Jes1 to jakby konieczny „krok w tył”, weryfikacja wartości chwili bieżącej przez to, cojest bezpośrednio sprawdzone, co już było. Stąd więc najbardzicj pierwotne, niekiedy nawet prymitywne, formy poezji, przypominające wiersze z epoki pierwszych polskich kółek socjalistycznych. Stąd również bezpośrednie formy zawierania sojuszy, które wkrótce podda się próbie.

Przywódców społeczności strajkowej, czy oni tego chcą, czy też nie chcą, czyni się rzecznikami wszystkich zaprzepaszczonych ideałów, nie rozwiązanych spraw, tłumionych prawd. Społeczność strajkowa tworzy coś w rodzaju grupy pierwotnej, o istnieniu której rozstrzyga orientacja na „drugiego” człowieka, na współtowarzysza. Musi wówczas słabnąć, albo radykalnie zmieniać społeczną lokalizację, znaczenie symboli centralnych, a przez to społeczność starego typu organizacyjnego zostaje przekształcona w nową społeczność, np. typu religijnego i natychmiast odzyskuje pozytywny związek z symbolami wartości centralnych (idealnych), tylko że już o zdecydowanie odmiennym charakterze (krzyż, ołtarz). Jest to - jak można sądzić - adekwatny dla sytuacji strajkowej, dla psychologii grupowej, sposób polemizowania $z$ innymi symbolami centralnymi ${ }^{2}$. Strajk można określić automodelem konfliktu społecznego, czy - jak chce Victor Turner — „dramatu spolecznego", a jego

\footnotetext{
' Idzie tu o teksty poezji robotniczej publikowane w oficjalnych antologiach i zbiorkach wydawanych przez kluby robotników piszących. Pisałem na temat obiegów poezji robotniczej w szkicu pt. Wspólczesna poezja robotnikótu („Regiony” 1981, nr 2). Tekst niniejszy powstał w roku 1984 i jest „brakującym ogniwem” tamtego szkicu. Publikuję go dziś w pierwotnej postaci. W paru przypadkach aktualizuję bibliografię.

${ }^{2}$ Historię znaczeń, jakie przypisywano w środowiskach robotniczych znakowi krzyża, rekonstruuje wstępnie W. L. Karwacki w studium Wiedza historyczna robotników polskich, [w:] Polska klasa robotnicza. Studia historyczne, IX, Warszawa 1980, s. 151; por. tegoż: Znaki i symbole w rewolucji lat 1905-1907, „Dzieje Najnowsze”, Rocznik VII, 1975 , nr 3.

${ }^{3}$ Odwoluję się tu do koncepcji Victora W. Turnera prezentowanej m.in. w jego książce pt. The Ritual Process: Structure and Anti-Structure. Hormodsworth, 1974. Próbę etnologicznego komentarza do tekstów obiegu strajkowego dał Cz. Robotycki w artykule pt. Sztuka a vista. Folklor strajkowy („Polska Sztuka Ludowa” 1990, nr 2). autor artykułu akcentuje koncepcję ludowego, karnawałowego „przeistoczenia”, znaną z pism M. Bachtina. Nasze ujęcie jest próbą uchwycenia zarazem rytualnego i historycznego aspektu wydarzeń, a nade wszystko ich p r o ce s u a l n e go charakteru. Dla analiz poezji robotniczej okresu Wielkiego Strajku - 1980 istotne znaczenie posiada nie opublikowana w całości rozprawa A. Błaszkiewicz pt. Świadomość spoteczna robotnikóu a językowa formy jej uzewnętrzniania.
} 
zrytualizowane formy moźna uznać za projekcję (uniwersalną, choć naturalną teorię) „zmiany” społecznej, czy „przeistoczenia”. Rytuały kościelne (obrzędy religijne), charakterytyczne dla środkowej fazy strajku w Stoczni Gdańskiej, podtrzymywały i utrwalały te ogólne normy i wartości, które zadecydowały o ukonstytuowaniu się głębokiej w s póln o ty s t rajk u $\mathrm{j}$ ą $\mathrm{y} \mathrm{ch}$. Rytualne formy okazały się sposobem przezwyciężania społecznego konfliktu, najpewniejszym scenariuszem procesu „przeistoczenia”. Spoistość wspólnoty strajkujących, która wystąpiła jakby w imieniu wspólnoty „wyzwalających się” ludzi, zagwarantowana była wtedy nie poprzez więź polityczną, ani więź kooperacyjną, czyli więź pracy; nie poprzez więź lokalną czy świadomość etniczną, ale więź rytualną, obrzędową. Rytuał „zawieszał” i zarazem zastępował dotychczasowe wic̨zi, przedkładając ogólną normę jedności moraln o-e ty c z n ej. Dzięki wspólnej uczestnikom rytuału jednoznaczności symboli, naśladownictwu działań, wspólnocic wyobrażen, strajk przenikał do fundamentów ludzkiej psychiki i egzystencji. Z drugiej strony, rytuał penetrujący głęboko strukturę strajku, innymi słowy - strajk „rytualizujący się”, odnawiał i podtrzymywał pewien typ wspólnoty, a raczej w s pól no tow ośc i, dla której Turner rezerwuje łaciński termin communtas. Totalności strukturalnej, która usymbolizowana była w aparacic organizacyjnym władzy, przeciwstawia strajk a n t y s t r u k t u r ę, czyli ogniwo procesualności, innymi słowy: - hybrydyczną totalność zalcżności spontanicznych, a więc totalność communitas. Więziom typu organizacyjnego (formalna struktura władzy, administracji zakładowcj itp.) przeciwstawił strajk więzi typu obrzçdowego, tworząc dogłębną wspólnotę cgzystencjalną.

W sytuacji strajkowcj wzmacniają swą pozycję symbole grupowej i klasowej tożsamości. Następuje powrót do „tekstów-wyjściowych”, które sytuacja strajkowa odkrywa, pospiesznie rekonstruuje dla własnych, bieżących celów. Powrót do form modelowych i „tekstów wyjściowych" miał swoje - wielokrotnie w historii potwierdzone - uzasadnienie. Władysław L. Karwacki odnotowuje w związku z tym, iz — chociaż powstało wiele piosenek „śpiewanych przez członków tylko jednej partii socjalistycznej” — „Nigdy (natomiast — R. S.) nie utraciły aktualności napisane przez pierwszych socjalistów polskich i śpiewano je zawsze z racji ich uniwersalizmu, pozbawione bowiem były niuansów polityczno-programowych i wyjawniały podstawowe prawdy o istocie wyzysku klasowego" ${ }^{4}$. Podobnie teksty z powszechnej pamięci pokoleń, teksty kanonicznc, sprzyjały odczuwaniu prawd elementarnych. Władysław L. Karwacki stwierdza np., że „Picśń religijna Boże, coś Polskę stała się w latach rewolucji 1905-1907 uniwersalną pieśnią, wyrażającą zarówno uczucia religijne, postawy patriotyczne, cele kontrrewolucyjne, jak i radykalne nastrojc. Nic słowa były ważne, lecz intencje śpiewającego" ${ }^{5}$.

+ W. L. Karwacki, Piosenka u' środowisku robotniczym, [w:] Polska klasa robotnicza. Studia historyczne, V. Warszawa 1973, s. 143.

${ }^{5}$ W. L. Karwacki, Żu'ot robotnika w pieśni, [w:] Polska klasa robotnicza. Studia historyczne, VIII, Warszawa 1978, s. 306 . 
W roku 1980 zaistniała elementarna potrzeba cofnięcia się do źródeł obrzędowości robotniczej, do języka z epoki pierwszych świadomych zrywów robotniczych, do symboliki religijnej i powszechnych tradycji humanistycznych. Najdogłębniejsze znaczenia strajku, jako wspólnoty egzystencjalnej (communitas) dadzą się z grubsza opisać w ramach teorii obrzędów przejścia, którą Turner zapożycza od jej twórcy - A. van Gennepa. Sytuacja strajkowa, będąca wykładnikiem, czy wręcz automodelem „dramatu społecznego” (kryzysu) rozpada się na: a) fazę separacji, b) fazę liminalną („,progową”), c) fazę rekonstrukcji.

Faza se paracji polegalaby tu na „zamknięciu się”, odizolowaniu za murem stoczni. Rytualnymi znaczeniami obciążona jest przede wszystkim „brama” (próg) oraz mur i płot graniczny. Następuje oznakowanie przestrzeni i oznakowanie siebie symbolami „separacji”, „odcięcia się".

Faza $\lim$ in a ln a (progowa) powoduje, iz jednostki i grupy osiagają status „dwurzeczywistości", a więc przechodzą do takiej sfery, czy przestrzeni kulturowej, która nie może być ani „tu”, ani „tam”. Nie może być odniesiona ani do tego, co „było”, ani do tego, co „będzie”. Wspólnota strajkująca nie jest już wspólnotą pracowników stoczni sprzed strajku, ale też nie zna jeszcze rozstrzygnięcia, nie zna tego, co przyniesie przyszłość. Jest więc czymś „nieukształtowanym”, „zarodkowym”, czymś - w danym momencie — jakby „,bez właściwości”.

Faza rekonstrukcji zamyka proces „przeistoczenia” („przejścia”). Uczestnicy „przeistoczenia” uzyskują na nowo stabilną pozycją, gdyż otrzymują prawa i obowiązki w ramach nowej struktury, której jedną z wykładni mogą być nowe wolne związki zawodowe.

Dla prób uchwycenia istoty strajku najważniejsza okazuje się faza p ro gow a (liminalna), antystrukturalna; jakby „zawieszona” między zastaną strukturą i strukturą proj e k t o w a n ą. Przeciwstawienie się strukturom centralnym, usymbolizowanym w znakach władzy, musi przejść (czy dokonać się) za sprawą fazy antystrukturalnej, czyli „progowej”. Rytuał strajkowy w tej fazie jest hipotezą rozpadającej się całości. Strajk, choć może tylko przelotnie i momentalnie (w symbolach, gestach, działaniach i języku), objawia nadrzędną, wszechobejmującą zastaną c a łość w momencie rozpadu. Sytuacja „progowa” jest więc zalążnią, potencjalnością struktury alternatywnej. Wspólnota strajkowa w fazie liminalnej jest wspólnotą ludzi „bez właściwości”. Wyodrębnia się i odcina od reszty zastanego świata poprzez te same, dla wszystkich jej uczestników, oznaki, plakietki, opaski, emblematy, orientację na „swoich” przywódców. Wspólnotę stanowią ludzie wyzwoleni $z$ dotychczasowych statusów, miejsc, stanów, sytuacji, pozycji w przestrzeni i czasie. Demonstracyjnie eksponuje się brak jakichkolwiek z dotychczas znanych właściwości. Galeria wspólnot i jednostek liminalnych jest w historii bogata. Mógłby otwierać ją człowiek wielkich Utopii, człowiek karnawału, rewolucji, człowiek „pogranicza”, artysta i prorok.

Powrót do zachowań i tekstów wyjściowych był w tej — jednorazowej totalnej artykulacji współczesnych dążeń klasy robotniczej - Wielką Weryfikacją, ośmielimy się to tak określić: — stuletniego dorobku polskiego ruchu robotniczego, był dramatycznym świętem stulecia 
tego ruchu. Można powiedzieć, że obserwowaliśmy w jakimś sensie filogenezę historycznej i politycznej świadomości robotników polskich w ontogenezie świadomości kształtującej się społeczności strajkowej. Takie właśnie Wielkie Weryfikacje towarzyszą ogromnym przeobrażeniom jakościowym, są narzędziem i współkomponentem wielkich przeobrażeń.

Życie społeczne jest procesem dialektycznym - twierdzi V. Turner. Polega na nieustannym włączeniu się to w communitas, to w s t r u k t u ry, w żywioł i w hierarchie, w związki „równości” i „nierówności”. V. Turner dodaje, iż w rytuałach „przejścia” ludzie wyzwalają się ze struktur na rzecz wspólnoty (wspólnotowości) tylko dlatego, aby powrócić do struktury jako ludzie „odrodzeni” doświadczeniem wspólnoty. A więc struktura i wspólnota, hierarchia i żywioł, to fazy następujące po sobie. Człowiek pragnie uczestniczyć w obydwu tych modalnościach. Ludzie, którym życie codzienne przynosi niedostatki i poczucie niedoskonałości pragną elimiancji tych niedostatków w rytualnej liminalności. Jednostki i grupy usytuowane „nisko” w strukturze dążą do rytualnego „wyniesienia”. Przedstawiciele struktur usytuowanych wysoko dążą do symbolicznej communitas i poddają się różnym niedogodnościom na drodze do jej osiągnięcia. Próba takich działań symbolicznych, zmierzających do przywrócenia „równowagi” struktury można przypisać władzom PRL w roku 19561970.

Wielki Powrót jest zawsze również Wielkim Zerwaniem, przemianą „skokową”, rewolucyjną. Na podobne procesy w historii polskiego ruchu robotniczego zwracał uwagę, cytowany wyżej Władysław L. Karwacki: „Jeżeli porównamy zachowania i postawy robotników łódzkich w czasie buntu w 1892 r. i rewolucji 1905 r., to uwidoczni się olbrzymi skok $\mathrm{w}$ wiedzy politycznej (co nie jest równoznaczne ze świadomością klasową) całej klasy robotniczej. Ze znanych nam relacji o wydarzeniach w 1892 r. wiemy, że robotnicy porzuciwszy pracę wylegli na ulicę, ale stanowili bezładną masę, bez określonego programu działania, który można by określić na podstawie widocznego symbolu. Podobnie jak w czasie burzenia maszyn, kiedy jeden z przywódców mianował się „królem Herodem”, tak w 1892 r.

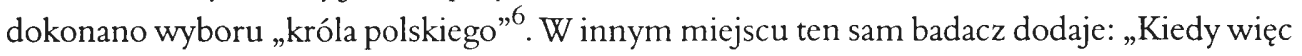
po raz pierwszy łódzcy tkacze w czasie burzenia maszyn w $1861 \mathrm{r}$. wylegli na ulice, towarzyszyły im tylko okrzyki, gwizdanie i co najwyżej... „kocia muzyka”. W czasie buntu łódzkiego w 1892 roku najczęściej rozlegała się pieśń Boże, coś Polskę i Jeszcze Polska nie zginęła. Gdyby śpiewano bardziej buntownicze pieśni, źródło, z którego czerpiemy te informacje („Przegląd Socjalistyczny”, październik 1892) zapewne odnotowałby ten fakt”" Zasadniczo nowa jakość wiedzy politycznej i historycznej towarzyszyła wydarzeniom 1905-go roku. „W rewolucji 1905 r. robotnicy powszechnie i bezbłędnie już określali charakter manifestacji i poglądy ich uczestników na podstawie sztandarów, traktowanych już jako symbole, za którymi dostrzegali

\footnotetext{
${ }^{6}$ W. L. Karwacki, Badania nad kultura robotniczq w Polsce, „Dzieje Najnowsze”, Rocznik VI, 1974 , nr 1.

7 W. L. Karwacki, Piosenka w środowisku robotniczym, op. cit.
} 
odpowiednic treści, postawy i emocjc. W masic robotnicy nie znali i nie wnikali w szczegóły programów, wiedzieli jednak dokładnie, kto manifestujc pod czerwonym sztandarem, kto pod biało-czerwonym, czarnym (anarchiści, manifestacja głodowa). Feretron kościelny w procesji określał inne treści, a inne w manifestacji politycznej Chrześcijańskiej Demokracji. W ramach trzynastu lat, między 1892 a 1905 dokonały się zasadnicze przemiany w strukturze politycznego myślenia całej klasy, a nie tylko grup politycznie uświadomionych robotników”".

Można powiedzieć, że podobnie głębokie przemiany jakościowe dokonały się dziś w czasie jednej dekady: 1970-1980. Warto w tym miejscu zauważyć, iż za puentę większości tekstów mówiących o wydarzeniach roku 1970-go można uznać ostatnią zwrotkę piosenki Grudniowe chmury... „Aż wreszcie w Polsce jest radość wielka // Bo mamy w rządzie Edwarda Gierka. // Bo on na pewno dziękuje Bogu // że nigdy w Polsce nie będzie głodu”. Była to niekłamana radość, że oto przychodzi nowy pierwszy sekretarz, nowy premier i wszystko się odmieni. W pełni potwierdza to również anonimowy tekst Ballady o Szczecinie utrzymany w konwencji pieśni dziadowskiej.

\section{Ballada o Szczecinie}

Posłuchajcie Państwo w głowie się nic micści

Posłuchajcie Państwo mojej opowieści,

Dnia 17 grudnia roku pamiętnego

Stocznia wyruszyła na pałac grubego 9

Spalili mu fotel i jego organy

Zostały mu tylko zgliszcza i parkany

Choć był taki mocny i miał tyle siły

Przed polskim stoczniowcem schował się do gliny

Choć miał w ręku czołgi i organ milicji

Przestraszył się naszej polskiej rewolucji

Wyjechały czołgi na nasze ulice

Postawili krzyże na każdą dzielnicę

Zabili nam ojców, dzieci nasze matki

Pożarli je w nocy jak hieny odpadki

A to wszystko na to, ze Polak pamięta

Że walczy o wolność, nie radzieckie pęta

Grabili nas wszyscy, począwszy od góry

Pochowali mięso, zostawili wióry

A z tej zachłanności Gomułka aż oślepł

\footnotetext{
${ }^{8}$ W. L. Karwacki, Badania nad kulturq robotniczq w' Polsce, op. cit.

${ }^{9}$ Komitet wojewódzki PZPR w Szczecinie, którego sekretarzem był Antoni Walaszek.
} 
Józef ${ }^{10}$ zabrał resztę według swoich potrzeb

Pożałował chlcba dla polskiego grodu

Czołgów nie żałował bo miał je ze wschodu

Lecz Polak pamięta, że pochodzi z Piasta

Powołał więc Gierka na wodza i basta

Dziś nadzieje w naszym gospodarzu

Że nie wróci grudzień w naszym kalendarzu

Wiersze i piosenki z roku 1980 takich puent nie miały.

Dla poznania złożonego charakteru Wielkiego Powrotu poezja strajkowa jest źródłem jednostronnym i fragmentarycznym. Im bardziej adekwatny, wielostronny, był organizacyjny wyraz strajku, szczególnic w fazie prowadzenia oficjalnych rozmów (transmisje przez głośniki, publiczne wystąpienia przedstawicieli stron, rejestracje na taśmach magnetofonowych, wreszcie krajowy i światowy zasięg wydarzeń) tym bardziej, okolicznościowa poezja strajkowa, musiała redukować zakres swych, zrazu rozlicznych, funkcji. Jej sens stawał się coraz bardziej jednostronny, fragmentaryczny, jednoaspektowy. Coraz silniej i coraz ściślej ca łość tego teatrum politycznego musiała określać funkcje tekstów poetyckich, zarówno ustnych, jak też funkcjonujących w formic powiclaczowej. Wiązało się to również z faktem, żc ustny obieg słowa, wypełniający czas foniczny (mówienie — słuchanie) zarezerwowany był dla innych celów (transmisje, nabożcństwa, komentarze lidcrów grup ekspresyjnych i organizacyjno-strajkowych, zbiorowy śmicch, brawa, docinki itp.).

Strajk, będąc totalną formą ekspresji, odebrał wiele znaczeń poezji obiegu folklorystycznego i strajkowego.

Poezja obiegu floklorystycznego, charakterystyczna raczej dla okresów względnie stabilnych, gdzie wykonanie pojedynczego tekstu zwiastuje sytuację totalną, wpisuje sens w słowa i gesty wykonawcy. Poezja strajkowa, także pod względem informacyjnym, jest wyraźnie ,jednoelementowa" i najwyraźniej niesamodzielna, kulturowo i estetycz$\mathrm{n}$ ie $\mathrm{nieau}$ tonomicz na. Jest ona raczej zbiorem tekstowych odniesicń do rytmu życia społeczności strajkowej, falowania nastrojów, pojawiania się spraw błahych i najważniejszych. Bez próby opisu psychospołecznej tkanki sytuacji strajkowej trudno wskazać podstawowe funkcje, jakie ta poezja pełniła. Można w tym miejscu wspomnieć jedynie, że zdolna była tworzyć krótkotrwałe, choć powtarzalne w czasic (często analogiczne) mikrośrodowiska nadawania i odbioru. Neutralizując prawie zupełnie treści informacyjne, estetyczne, czy kontemplacyjne, poezja ta pełniła przede wszystkim funkcje więziotwórcze. Tworzyła dyskretne struktury psychospołeczne, które stawały się najpewnicjszą, najbardzicj adekwatną

${ }^{10}$ Józef Cyrankiewicz, premier ówczesnego rządu. 
płaszczyzną porównywania i uzgadniania znaczeń słów, gestów i najskrytszych emocji. Nie były to przecież wiersze do czytania w pojedynkę. Pojedyncza lektura nie mogła być lekturą pełna. Poezja strajkowa pełniła funkcje regulacyjne, terapeutyczne i więziotwórcze. Tworzyła mikrostruktury solidarności grupowej, była nośnikiem (nawet formalnym, „pozatreściowym”) takich fundamentalnych składników etosu robotniczego, jak braterstwo, solidarność, duma czy godność. Wszystkie te wartości wyrastają ze społecznego usytuowania robotników przez pracę.

Praca, którą przerwano, nie mówiła już „przez siebie”, ale mówiła o sobie. Strajk najlepiej nazywał pracę, okazał się gruntowną autoanalizą pracy. Praca rzeczywista milczy wówczas, kiedy woła najgłośniej w poezji antologijnej.

\section{2.}

Strajk „strajkujący”. Wydarzenia Sierpnia 1980 wywołały całe serie robotniczych wierszy, które zyskały ogromny rezonans publiczny. Poezja obiegu antologijnego i klubowego, która była poezją „bez publiczności” (bez czytelników) została nagle wymieniona na całą formację poezji, która jakby zatracała swój przedmiot estetyczny, konieczne minimum autonomii poetyckiej. Stawała się zbiorem sygnałów słownych, organizujących i regulujących nastroje publiczne w wymiarze bardzo konkretnym: wśród załóg robotniczych, zawiązujących się i rozpadających wspólnot, kręgów środowiskowych itp. Znaczenia tej poezji „roztapiały się” w pulsowaniu intencji i programów najróżniejszych grup społecznych i wspólnot, które tworzyły się w obrębie gwałtownie „poruszonej” struktury społecznej. To społeczeństwo w sensie globalnym zawładnęło znaczeniami (obrazami i symbolami) twórczości strajkowej.

Poezja robotnicza w całej powojennej historii nie miała takiej publiczności, tak mocnego zaplecza i argumentacji. Nigdy do tej pory, poza - być może - wydarzeniami lat 1905-1907, nie stanęła na tę skalę oko w oko z czytelnikiem. Rezonans publiczny robotniczej poezji został — jak się wydaje — zrozumiany niekiedy zbyt powierzchownie, a jej znaczenia, w pewnych przypadkach, zostały przecenione. Sądzę, że dotyczy to przede wszystkim licznych wówczas wypowiedzi politologów, publicystów, socjologów, którzy niejako z zawodowego obowiązku zajmowali się, także przed rokiem 1980, obserwacją i analizą rytmów życia spolecznego w Polsce. Poezja robotnicza została nagle jakoby „odkryta”, uznana za ewenement socjologiczny, a przede wszystkim została potraktowana jako źródło do poznania tego, co się wydarzyło. Dziś już jesteśmy bardziej pewni tego, że nie była to mocna przesłanka podejmowanych wówczas diagnoz. Wiersze robotnicze i w środowisku robotniczym funckjonujące, stały się nie tylko wymownym dokumentem czasu, ale także symbolem, a nawet swoistym mitem społecznym. Natomiast dla poetów robotniczych nawet tych, którzy funkcjonowali przed Sierpniem w obiegu antologijnym i klubowym, wydarzenia roku 1980, stały się impulsem oczyszczającym, weryfikującym podstawowe treści etosu robotniczego, wyzwalaja- 
cym nowe formy wyrazu poetyckiego. Najlepsze wiersze ${ }^{11}$, odwołujące się do e le m e nt a r ny ch for m ekspresji słowa, powstały w sferze bezpośredniego oddziaływania wydarzeń roku 1980. Otwiera je bogaty nurt w i e r s z y r o z l i c z c n i ow y c h, które zyskują jeden z najlepszych przejawów w tekście górnika z kopalni „Pstrowski” - Jana Majowskiego, zatytułowanym Kto rano wstaje, temu Pan Bóg daje, a zwracającym się wprost do I sekretarza KC PZPR - E. Gierka

Oj kolego, mój kolego, coś ty nam narobil, Tyś Ojczyznę pozostawil, jak po białym ogniu.

My na ciebie tak liczyli, jak na swego chłopa, dłonie same głośno biły i wołały sto lat.

Zeby to tak w sny zamienić i wymazać z myśli, teraz trzeba się rumienić i zawałek bliski.

Oj Huteczko ${ }^{12}$, w kość nam dałaś, zatrzymałaś zbiory,

ty Bogdanko ${ }^{13}$ dochód rwałaś, rozszerzałaś wody.

Szły węglarki towarowe do Szczecina, Gdańska.

$\mathrm{U}$ rolnika w oborze zamiast prosie - kartka.

Taka sama też wisiała w każdym polskim sklepie, tylko Pani dopisała, trzeba wstawać wcześnie.

6 września 1980

"Publikowane w niniejszym szkicu teksty zgromadziłem podczas badań nad kulturą środowisk robotniczych w latach 1975-1984.

${ }_{12}$ Chodzi tu o Hutę Katowice.

${ }^{13}$ Kopalnia na terenie Lubelskiego Zagłębia Węglowego znana z trudnych warunków geologicznych. 
Na uwagę zasługuje również litanijno-lamentacyjny wiersz Franciszka Gugoła, robotni ka i działacza partyjnego z Rudy Śląskiej:
Oj, boli nas, boli
to serce górnicze,
co jak sztandar rozdarty
na wietrze łopocze.
$\mathrm{O}$, boli nas, boli
to serce robocze,
co było sprzedawane
za węglowe krocie.
Oj, boli nas, boli
to serce czerwone,
takie pełne śmiałości,
dzisiaj zatracone.
Lecz my z tej boleści
samej nie żyjemy,
tylko z naszej roboty,
$z$ niej siłę czerpiemy.
I chociaż dokola
jakoś „dziwnie szumi”,
górnicy pozostaną
sercowo czerwoni.

(pisane w Barburkę roku 1980)

Wśród poetów spoza obiegu antologijnego silnie zaznaczył się n u r t refle k s y j y prezentowany m.in., przez wiersz Karola Kawskego, robotnika z Włocławka, zatytułowan: $W$ sierpniouych dniach 1980:

Uzbrojeni w ręce
robotnicy
z sumieniem czystym
w sierpniowych dniach
zgodni optymiści
zdolni do wyrzeczeń
choć leżał na stole
chleb
i nóż
odrębne dwie rzeczy

(grudzień 1980)

czy wiersz pt. Zaduma napisany przez Piotra Brzezińskiego (Bartka Przekornego): 
Choć odtąd naszą polską teraźniejszość wyznaczać mogą coraz wyższe krzyże, przcz krzyże nie jest bliższe człowieczeństwo, ani socjalizm nie jest przez nie blizej.

Bo chociaż rozum powinien być siłą na każdy Grudzień i na każdy Sierpień, znów nam symboli męczeństwa przybyło, bezsennych nocy, przypominanych cierpień.

Choć jest cierpienie iskrą buntu tłumów, zdolną na mury Bastylii je rzucić, nie wszystkich równo naucza rozumu. Tych, co nie cierpią, rozumu nie uczy.

(17 grudnia 1980)

Przytoczone wyżej wiersze, którym przypisuję walor typowości, były współkomponentem nastrojów, emocji, idei i zachowań w sytuacji roku 1980. Poświadczają one powrót do źródeł świadomości robotniczej, odnawianie się treści etosu robotniczego, a jednocześnic potwierdzają proces wyzwalania się poetów robotniczych z przymusów formalnych, organizacyjnych; uwalniania się od rygorów obiegu antologijnego, klubowego, stowarzyszonego itp. Przymusem twórczym, u autorów najlepszych tekstów, staje się rozbudzona samowiedza historyczna, polityczna i w najmniejszym chyba zakresie — artystyczna. Wszystko to pojawia się w kręgu oddziaływania idei, symboli, nastrojów i rytuałów strajku „p rzeistac z a j ą c e g o "; pojawia się jako promieniowanie głc̨bokich prawd wspólnoty spontanicznej, czyli communitas.

Odwolując się powtórnie do koncepcji Victora Turnera, można zaproponować, ogólnikowy wprawdzie, opis reguł przekształceń wszelkich wspólnot typu spontanicznego. Spontaniczność zawiera w sobie zapowiedź struktury, hierarchii i normy. Strajk „strukturalizuje się”. Wspólnota typu spontanicznego (egzystencjalnego) przekształca się nie tylko codziennie od nowa, ale także $z$ dnia na dzień, z tygodnia na tydzień, we wspólnotę typu n o r m a ty w n e g o i wreszcie - i d e o l o g i c z n e go. Strajk wówczas „strajkuje”, „strajkuje” przeciwko sobie, gdyż takic jest prawo przekształceń strukturalnych. Kiedy strajkująca wspólnota spontaniczna uformuje się jako względnie mocny system, wzmaga się wówczas potrzeba ustanowienia socjalnej kontroli, po to, aby communitas podtrzymać. Kiedy strajk „strajkuje” przeciwko sobie, pojawia się wówczas wspólnota typu ideologicznego. Turner sądzi, iż wyrasta ona z konieczności uzmysłowienia, zarówno jawnych, jak i ukrytych, efektów przeżywania egzystencjalnej communitas. A wszystko to zmierza do zoptymalizowania społecznych warunków przedłużenia i zintensyfikowania doświadczeń oddziałującej wspólnoty egzystencjonalnej. Można przyjąć, żc odpowiada to sytuacji z przełomu roku 1980 i 1981, a takżc późniejszcj, kiedy nastąpiły już zasadnicze „przesunięcia” i reinterpretacje konfliktu 
sierpniowego. Poezja strajkowa, utraciła w znacznym stopniu, po roku 1980, swoje podstawowe funkcje r e g u l a c y j e i w jakimś sensie nawet e s c h a t o log i c z n e, dominujące w Sierpniu. Odwoływała się natomiast coraz częściej do pierwiastków l u d y c z n y c h , bądź też ulegała wtórnej mitologizacji, swoistej sakralizacji.

Strajk sierpniowy, jako „klasyczny spektakl” narodowy naszej najnowszej historii, zyskiwał setki i tysiące replik regionalnych. Przestawał być tylko formą walki, formą „przeistaczania", stawał się po trosze — sposobem bycia. Niekiedy do zakładu pracy przychodziło się nie „do roboty”, ale „na strajk”. Robota jednak musiała istnieć choćby w takim wymierze, aby mógł znaczyć, mógł „zaistnieć” sam strajk. Słowa poezji strajkowej umierały wówczas bardzo szybko, coraz częściej pełniły funkcje stabilizujące, a nie zmieniające.

Wspólnoty typu normatywnego oraz ideologicznego — jak pisze Turner — są już „we władaniu" struktury, antystrukturalną jest jedynie wspólnota egzystencjalna, spontaniczna. Struktura rodzi, jako swoje zaprzeczenie, albo spontaniczność, albo k o n trs t r u k t u rę, która z kolei rodzi idee ponownego ładu, nowe przymusy strukturalne; rodzi nowe teksty, znaki i symbole.

Przewaga czy dominacja „struktury” może prowadzić do patologicznego wręcz pojawiania się communitas „z zewnątrz”, communitas przeciwko „prawu”. Natomiast dominacja communitas w określonych ruchach religijnych czy politycznych typu egalitarnego, rewindykacyjnego, może szybko przemienić się $\mathrm{w}$ despotyzm, biurokrację i przybrać jeszcze inne odmiany zaostrzonego reżimu „struktury”. Dominacji communitas nie można podtrzymywać tak długo, jak nie można długo podtrzymywać zastanej struktury prawnej czy politycznej. Communitas nie może obronić się na dłuższą metę przed wyhodowaniem, „wewnątrz” siebie, nowej struktury. Swobodne stosunki przekształcają się wtedy w relacje normatywne. Tak bowiem było we wszystkich spontanicznych communitas w historii. Np. w religijnych ruchach typu komunitarnego, z biegiem czasu, podlega zrutynizowaniu nie tylko charyzma przywódców, ale także i communitas ich pierwszych uczniów i następców.

Analiza strajku prowadzi, tropem wytyczonym przez Turnera, do analizy s p o łe c znych funkcji konfliktu, akcentuje społeczną doniosłość ne gatywnego doś w i a d c z e n i a, którego nie da się unieważnić, zneutralizować magicznymi zaklęciami, ani sprowadzić do niedorzeczności, do „warcholstwa”, awanturnictwa, czy przyrodzonego Polakom nieposzanowania prawa.

Skomplikowana dialektyka struktury i antystruktury przenika intensywny puls życia społecznego w roku 1981. Nastroje te w sposób symboliczny oddaje fragment wiersza K. Kawskiego:

\section{I znowu}

dzień się rozjątrzył jak wielka rana

w której maczamy palce

jak chirurdzy we wnętrzu ojczyzny (...) 
Zazwyczaj, w momencie gwałtownych przesileń, następuje nawiązanie do starych wzorców tekstowych, np. romantycznej poezji wygnań i powrotów; nawiązanie do powszechnych wzorców melodycznych. Chyba od czasu wojny i okupacji nie mieliśmy do czynienia z tak silnym odnowieniem „powszechnej pamięci estetycznej”, nie mieliśmy kontaktu z symbolami i znakami polskiej tradycji narodowej, jak w latach 1980-1981, a także kolejnych latach stanu wojennego. Odnowiła się tradycja „śpiewników” z takimi gatunkami p o e z j i k on i e c z n e j, jak lament, kolęda, hymn, litania, pieśń religijna oraz gatunki poczji l u d y c z n ej , na które złożyły się wzorce pieśni sowizdrzalskich, jarmarcznych i balladowych.

Teksty z obiegu folklorystycznego posługują się „zagęszczonym” czasem i materializującą się (konkretyzującą) przestrzenią. Są one projekcją tego, co n i e z n a n e , co może się zdarzyć w zgodzie z wzorcami pieśniowego świata, np. wzorcami pleniących się gwałtownie wróżb i przepowiedni. Opanowywanie i regulowanie socjopsychicznych konsekwencji gwałtownego przesilenia społecznego, w grudniu 1981 roku, znalazło wyraz najczęściej w pieśni religijnej, której znakomitym przykładem może być, popularna na Śląsku w latach 1981-1982 Madonna Czarna:

Jest zakątek na tej ziemi, gdzie pracować każdy chce, Gdzie króluje Jej oblicze, na nim cięte rysy dwie, Wzrok ma smutny, zatroskany, jakby chciała prosić Cię, Byś w matczyną jej opiekę oddał się.

Ref. Madonno, Czarna Madonno, jak dobrze Twym dzieckiem być.

O pozwól Czarna Madonno, w ramiona Twoje się skryć.

W jej ramionach znajdziesz spokój i ochronisz się od zła, Bo dla wszystkich swoich dzieci Ona czułe serce ma.

I opieką cię otoczy, gdy Jej serce oddasz swe,

Gdy powtórzysz Jej z radością słowa te:

Ref. Madonno, Czarna...

Dziś gdy wokół nas niepokój, gdzie się człowiek schronić ma, Gdzie ma pójść, jak nie do matki, która ukojenie da.

Więc błagamy, o Madonno, skieruj wzrok na dzieci swe

I wysłuchaj, jak śpiewamy, prosząc Cię:

Ref. Madonno, Czarna...

Regulacyjne funkcje tekstów z obiegu folklorystycznego ujawniły się również w utworach eksponujących pierwiastki humorystyczne, tony żartobliwe, co widać choćby w następujących dwu fragmentach; fragmencie „zapowiadającym”:

Ekstrema już śpi,

Szczekają gdzieś psy

I kończy się wolna sobota... 
i fragmencie "finalnym":

Sklep bez towaru, koń bez podkowy

Naród bez wódki spokojny.

Człek jest bez butów, (...)

A stan wojenny bez wojny.

Eksponowana w naszych rozważaniach koncepcja V. Turnera podsuwa pomysły „etnograficznego" badania zjawisk i ruchów politycznych, uzasadnia też semiotyczną metodę badania działających ideologii oraz ich znakowych nośników w postaci tekstów poetyckich, wszelkiego typu przekazów językowych.

Turnerowska dialektyka procesu społecznego, polegającego na skomplikowanej przemienności i następstwie „struktury”, ,antystruktury” (communitas) i „kontrastruktury” wyznacza losy obicgów poezji robotniczej, która, jak pisaliśmy już wcześniej, nie jest zjawiskiem samoistnym estetycznie i bardzo rzadko jej teksty powstają i funkcjonują w oderwaniu od znaczeń chwili bieżącej, od rytmu naszych kryzysów, czy faz kryzysy te zapowiadających. Teksty poezji robotniczej nie scalają się jako trwałe sensy estetyczne, pomimo iż posługują się one niezwykle trwałą formą językową, powielającą stereotypy i obrazy powszechnej pamięci estetycznej. Stąd też twórczości tej można przypisać status poe zji okolicznościowej, w zgodzie z definicją, którą posługują się historycy literatury, akcentując polityczne funkcje tych masowych zjawisk poetyckich. Teksty okolicznościowe „nie przedstawiają (...) zdarzeń historycznych w sposób obiektywny, z perspektywy zamkniętego już w sobic ich przebiegu; utwory te należą do wciąż jeszcze trwającego procesu dziejowego; wyrastają one ze zdarzeń jako ich bezpośredni skutek, a najbliższym ich celem jest oddziałanie na dalszy bieg spraw drogą wywarcia wpływu na usposobienie ludzi oraz zdobycia w narodzie zwolenników dla pewnej określonej koncepcji rzeczywistości bieżącej. Dlatego właśnie utwory te ze swej wewnętrznej istoty nie są z natury historycznej, ale właśnie politycznej czy polityzującej” ${ }^{14}$. Ten obszar zjawisk poezji robotniczej wydaje się, jak do tej pory, najbardziej doniosłym społecznie i przez to znaczącym kulturowo. Trzeba przyznać, że to nie w żadnym innym, ale w środowisku robotniczym, bądź na tego środowiska zamówienie, powstały i funkcjonowały najbardziej istotne przejawy literatury okolicznościowej ostatnich dziesięcioleci.

Jeśli spojrzy się na repertuar ustny z perspektywy połowy lat osiemdziesiątych, to da się wyprowadzić wniosek, że w folklorze współczesnym nie da się odnotować trwałych przeobrażeń jego zasobów. Zaledwie kilka tekstów (trzy, lub cztery), znanych przed rokiem 1980,

${ }^{14}$ Por. J. Nowak-Dlużewski, Okolicznościowa poezja polityczna w Polsce. Średniouriecze, Warszawa 1963, s. 5-6. 
funkcjonowało w okresie Sierpnia i wydarzeń po roku 1980. We współczesnym repertuarze ustnym można zatem odnotować zmiany nie tyle trwałe, ile gwałtowne, kiedy to setki tckstów, zazwyczaj jednak „utrwalonych” w formic zapisu magnetofonowego czy powiclaczowego, wypierane są z obiegu folklorystycznego pod wpływem wydarzeń chwili bieżącej, przez setki innych tekstów, jak miało to miejsce chociażby na przełomie roku 1981 i 1982. Tym bardziej, że były to wydarzenia już nie w skali lokalnej, ale ogólnej. Nowy repertuar zaistniał wówczas jakby ponad obiegami środowiskowymi czy regionalnymi, dopracowując się dopiero później lokalncgo czy środowiskowego kolorytu. Wkrótce jednak uległy neutralizacji jego treści i funkcje polityczne, na rzecz funkcji ludycznych, jak również na rzecz pogłębienia i rozszerzania się związków tego repertuaru z obrzędowością kościelną. 